\title{
Soil quality restoration through carbon sequestration under climate change scenario in India
}

\author{
A.A. PATIL, B.Y. SHEWALE AND S.R. KADAM
}

Received : 13.10.2014; Accepted : 29.11.2014

\author{
MEMBERS OF RESEARCH FORUM: \\ Corresponding author : \\ S.R. KADAM, Department of Soil \\ Science and Agricultural Chemistry, \\ Mahatma Phule Agricultural \\ University, Rahuri, AHMEDNAGAR \\ (M.S.) INDIA \\ Email: shubhangipatil2612@gmail.com \\ Co-authors : \\ A.A. PATIL AND B.Y. SHEWALE, \\ Department of Soil Science and \\ Agricultural Chemistry, Mahatma \\ Phule Agricultural University, Rahuri, \\ AHMEDNAGAR (M.S.) INDIA
}

\begin{abstract}
Summary
Climate change has emerged a major challenge not only for sustainable agriculture but also for human settlement. Climate change including global warming with its adverse impact on the life on the earth is now global issue and becoming severe day by day. The increase in $\mathrm{CO}_{2}$ concentration results in climate change which is directly or indirectly attributed to human activities that changes the composition of global atmosphere adversely. Scientific models and observations over the past 1000 years provide evidences that global warming is due to anthropogenic increase in green house gas (GHG's)including that of $\mathrm{CO}_{2}$. The increased atmospheric concentration of $\mathrm{CO}_{2}$ may influence soil temperature, pattern of precipitation and evaporation and resultant changes in the physiochemical and biological properties of soil. Thus, there has emphasis to reduce this concentration through the process known as carbon sequestration. A considerable part of the depleted Soil Organic Carbon pool can be restored through conversion of marginal lands into restorative land uses, adoption of conservation tillage with cover crops and crop residue mulch, nutrient cycling including the use of compost and manure and other systems of sustainable management of soil and water resources.
\end{abstract}

Key words : Soil quality, Carbon sequestration, Climate change, Soil organic carbon

How to cite this article : Patil, A.A., Shewale, B.Y. and Kadam, S.R. (2014). Soil quality restoration through carbon sequestration under climate change scenario in India. Asian J. Soil Sci., 9(2): 311-317. 